\title{
Use Assessment Screening Socio-Emotional Development by Teachers Playgroup
}

\author{
Yulinda Paripurnanti, Mustaji \& Miftakhul Jannah \\ Universitas Negeri Surabaya \\ Surabaya, Indonesia \\ yulindaparipurnanti@gmail.com
}

\begin{abstract}
For educators, it is very important to know how easy and can be done to recognize the child's emotional and social behavioral symptoms and their effects. Some of the simple abilities that educators need to master in recognizing the emotional social behavior of children are the ability to observe or observe identifying the various emotional and social characteristics of the child, and the ability and skills to record, record and make predictions about what actions will accompany them. The screening process is one form of assessment to identify early childhood development that has problems that have not been clearly visible or neglected. Through the screening assessment, the educator can understand the objectives to be achieved, important information needed, implementation time and methods to be used in the screening assessment. Assessments conducted through screening will help educators to inform early childhood development.
\end{abstract}

\section{Keywords- Screening Assessment; Social-emotional} Development; Playgroup; Teachers.

\section{INTRODUCTION}

Early childhood is the basic foundation for further growth and development [1]The development of children is the phase of physical growth, social, mental, and language that emerged from birth until 8 years of their age [6]. The knowledge of childhood development is fundamental for early childhood educators or teachers. This knowledge can help the educators implement the learning activities which are suitable for children development [9]. It is because implementing the learning activities needs teachers' knowledge and understanding of children's needs and characters as well as other influences of their growth and learning [2]

The knowledge of childhood development can be the foundation for teachers to do practice appropriately based on the age development Developmentally Appropriate Practices (DAP) as well as help teachers develop and implement the learning experiences in order to increase the learning activities for all children. The teachers and parents studying the development of children will increasingly understand about the proper way to educate children [3]The early age is a golden age because at this time the children begin to be sensitive to receive various stimulations from various educational efforts coming from the environment either intentional or unintentional. In this sensitive period, there is the physical maturation and psychic functions [12].

The sensitivity has an important meaning for every child's development. This means that if educators and parents know their children have entered a sensitive period and provide appropriate stimulation, it will accelerate the mastery of developmental tasks at their ages. Based on the constitution no. 20 of 2003 on National Education System, chapter 1, article 1, item 14, it states that Early Childhood Education (ECE) is a coaching effort aimed at children from their birth to six years old through the provision of educational stimuli to assist growth and development of physical and spiritual so that children have readiness in entering further education. Early childhood education is one form of education that focuses on laying the foundation toward physical growth and development (fine and coarse motor coordination), intelligence (creativity, thinking power, spiritual intelligence, and emotional intelligence), emotional social (behavior, attitude, and religion) of communication and language, in accordance with the uniqueness, characteristics, and stages of development going through my early childhood.

A born child needs the appropriate service for the fulfillment of educational needs along with an understanding of the characteristics of children according to their growth and development. This understanding will greatly assist the teachers, parents, and families in adapting the learning process for children of their ages, needs, and conditions, including intellectually, emotionally and socially. The fulfillment of the quality of the early childhood education should follow the standards of early childhood education based on the current regulations such as the presence of the educational facilities, the educators or teachers, and the adequate educational stakeholders. One of the responsibilities of the teachers in the child education is to observe, document, and conduct the assessments related to children's learning [12]. The assessment results that can be defined as the cognitive process of collecting information on the development, learning, behavior, academic progress, the need for specialized services and the success of the child in making the decisions will assist the teachers in providing information to be communicated with the parents and the children's families [2]. The assessment is part of activities to determine the level of individual learning achievement. 
According to [4] the assessment is the activity of collecting information about the quantity or quality of changes occurred in the learners. Learning is basically an activity to make changes to learners, the results, therefore, should be known. To know the magnitude and quality of this change, an assessment is made.

The screening assessment is one form of assessment that serves to identify the early childhood development that has problems and has not been clearly seen or neglected [2]. The assessments conducted through screening will help the educators as well as the teachers to inform early childhood development. According to [5] the main objective of the screening assessment is to identify the child in large groups so that it can be known if the child is experiencing delays in development, therefore, it requires special handling. On the other hand, Wortham (2005, p. 67) stated that the purpose of the screening assessment is to identify the strengths or weaknesses of the child ultimately to suggest appropriate strategies for the children's improvement [14]. A screening assessment is a process designed for the purpose of identifying potential problems in learning or development [5]In other words, it can be said that a screening assessment is a systematic process aimed at identifying early child development. Similarly, Dodge and Colcker (2001) emphasized that the development screening is a preliminary identification to evaluate the child in more depth, by obtaining preliminary data from the results of this screening, institutions of the early childhood education and educators that will be able to provide appropriate simulation and planning interventions for children as well as communicate with parents [5]. According to [6] the identification is the activity of recognizing or marking something, which is interpreted as the process of crawl or the process of finding a case that is finding a child who has a disorder or problem, or early detection of children [15]. According to [5]the screening assessment is the best option for looking at early childhood development, documenting progress, and identifying the late childhood development in the academic field. One of the questions that become the basis of the screening assessment is "Is my child ready for kindergarten?" [2].

The screening in early childhood supports the readiness of children to enter the next level of education by looking at their health and development. According to ("Department of Education Minnesota,"), the early years of childhood are very important in creating the foundation for learning and success. Therefore, the screening is best done when the child is 3-4 years old or within the first 30 days of a child entering the Kindergarten so that health problems or child development can be addressed early. The early years of the children's life are crucial in creating the foundation for learning and success. The screening is the process of measuring the children development in speech and language skills, motor skills, general knowledge, hearing and vision [7]The screening assessment that has been undertaken focuses on the emotional social development of playgroup children who have a 3-4 year age range. The researchers view that emotional-social development is very influential on the readiness of children in entering the next level of education [2]. The positive and negative emotional-social development will affect the quality of activity levels that can be done by the child in his life. A child's emotional reaction helps in the preparation of the condition of the body (physical, mental, psychological) to take action [8]

The activities performed according to the children emotions, then the child will feel happy when doing it and will mentally increase concentration on the activity memorize it, and psychologically will give a positive contribution to the increase of motivation and interest in the activities being persistent [10]. If the activity is a learning activity, it will be very supportive in getting a learning experience that is more meaningful and functional. In the implementation of screening assessments, the emotional social developments of educators are expected to improve pedagogic competence, with reviewing indicators, identifying the early ability of early childhood social development and early childhood language, identifying early childhood difficulties and classifying early childhood as needed in various aspects of development.

Based on constitution No. 14 of 2005 about teachers and lecturers, it is mentioned that teachers are the professional educators with the main task of educating, teaching, guiding, directing, training, assessing and evaluating learners in early childhood education, formal education, basic education, and secondary education. In Permendikbud no.137, 2014 about PAUD standard, it is explained that early childhood educators are professionals in charge of planning, implementing lessons, and assessing learning outcomes, as well as conducting mentoring, training, caring and protecting the children or students [12]. The implementation of their duties as educators, they should be guided by pedagogical competence as PAUD educator as stated in appendix II Permendikbud number 137, 2014 about PAUD Standard.

According to (California Department of Education, 2011), the competence of educators is divided into two types namely competency areas and competency contexts. Competency areas including (1) child development and learning, (2) culture, diversity, and equity, (3) relationship, interactions, and guidance, (4) family and community engagement, (5) duallanguage development, (6) observation, screening, assessment, and documentation, (7) special needs and inclusion, (8) learning environment and curriculum, (9) health, safety, and nutrition, (10) leadership in early childhood education, (11) professionalism, (12) administration and supervision.

According to [9] stated in this journal, it is explained that assessment is one of the most important parts of the education system which in this case is in early childhood education (ECE). The assessment can yield much information that can be used by educators and families in order to measure the learning outcomes. In addition, assessments can be used to overcome the obstacles experienced by children during learning and indirectly have a positive impact on the children and their families [3].

Based on the research journal of Early Childhood Assessment Aotearoa New Zealand: Critical perspectives and 
fresh openings [10] that early childhood teachers are in the best position to make decisions about teaching and learning in local and contextual settings, with and for children with whom they share it [1]. Furthermore, the Early Childhood Teachers as Socializers of Young Children's Emotional Competence [11]in this journal explain how important emotional competence for preschoolers to understand the mechanisms of how children develop emotional competence. Both parents and teachers are considered an important socializer of emotions, giving children experiences that promote or hinder the development of emotional competence. However, compared to parents, the role of early childhood teachers in socializing youth emotional competence has not been examined [4].

\section{METHOD}

This research used a quantitative research approach, especially in experimental research. This experiment was conducted to determine the effects of a deliberate treatment by the researcher [12] This study provides the treatment in the form of the use of screening assessments to determine the effect of the teacher's ability to identify the socio-emotional development of the playgroup children.

This study used a type of one-treatment pre-test-post-test design which is an experimental design that uses only one experimental group without any control groups by performing a one-time measurement of the dependent variable before the treatment is given [13]The pre-test serves to control the threat of internal validity that has previously been measured against the baseline or the initial ability of the participants in this study. The baseline then became the benchmark data of posttest [7]. This study conducted a one-time measurement of the teacher's ability, especially those related to the pedagogic competence of Playgroup teachers.

This study used non-probability sampling, using a saturated sampling technique whereas all the members of the population used as samples [14]Based on data obtained in the preliminary observation, the researcher got data from the number of Teachers Group in Sempu who consisted of 26 people, saturation sampling technique, therefore, was used because the population was relatively small and less than 30 people.

The validity used in this study was the validity of the construct by calculating the total item correlation using Product Moment Pearson which produces the correlation of corrected item-total coefficient and the validity content. Moreover, the reliability test of measuring instrument in this research was tested using internal consistency approach with alpha Cronbach computation technique. To calculate the validity and reliability is processed using SPSS 22.0 for windows technical assistance.

The data collection for pretest and posttest in this study emphasized the ability of teachers which was conducted by distributing the questionnaires to teachers of $\mathrm{KB}$ to be filled and then collected again. Furthermore, the questionnaires used in this research were questionnaires with the subjective approach, where the answers described the reflection of the respondent's self-condition. The statistical method used to test the hypothesis in this study was non-parametric statistics.
Hypothesis testing was carried out to find out the differences in $\mathrm{KB}$ teachers who were given treatment in the form of using screening assessments of children's social-emotional development. Wilcoxon test was applied to obtained data before and after treatment was given. Furthermore, the data analysis was done by using computation technique SPSS 22.0 for windows.

\section{RESUlT AND DisCUSSION}

The main objective of this study was to determine the effect of the use of social-emotional development screening assessment on teachers' ability in identifying children playgroup development. Before calculating the test hypothesis, it was conducted to calculate the validity and reliability.

THE RESULT OF INSTRUMENTS VALIDITY

\begin{tabular}{|c|c|c|c|c|}
\hline \multicolumn{5}{|c|}{ Item-Total Statistics } \\
\hline & $\begin{array}{l}\text { Scale } \\
\text { Mean } \\
\text { if Item } \\
\text { Delete } \\
\text { d }\end{array}$ & $\begin{array}{c}\text { Scale } \\
\text { Variance if } \\
\text { Item } \\
\text { Deleted }\end{array}$ & $\begin{array}{l}\text { Correcte } \\
\text { d Item- } \\
\text { Total } \\
\text { Correlati } \\
\text { on }\end{array}$ & $\begin{array}{c}\text { Cronba } \\
\text { ch's } \\
\text { Alpha } \\
\text { if Item } \\
\text { Delete } \\
\text { d }\end{array}$ \\
\hline item_1 & 34.46 & 40.738 & .689 & .873 \\
\hline item_2 & 34.77 & 43.065 & .405 & .884 \\
\hline item_3 & 34.65 & 40.555 & .598 & .876 \\
\hline item_4 & 34.88 & 42.746 & .501 & .880 \\
\hline item_5 & 34.85 & 42.855 & .432 & .883 \\
\hline item_6 & 34.62 & 38.406 & .782 & .867 \\
\hline item_7 & 34.96 & 41.958 & .506 & .880 \\
\hline item_8 & 34.85 & 42.535 & .469 & .881 \\
\hline item_9 & 34.54 & 40.098 & .731 & .870 \\
\hline $\begin{array}{c}\text { item_1 } \\
0\end{array}$ & 34.73 & 40.365 & .534 & .880 \\
\hline $\begin{array}{c}\text { item_1 } \\
1\end{array}$ & 34.88 & 43.706 & .436 & .883 \\
\hline $\begin{array}{c}\text { item_1 } \\
2\end{array}$ & 34.81 & 41.602 & .574 & .877 \\
\hline $\begin{array}{c}\text { item_1 } \\
3\end{array}$ & 34.81 & 40.162 & .632 & .874 \\
\hline $\begin{array}{c}\text { item_1 } \\
4\end{array}$ & 34.85 & 40.775 & .498 & .881 \\
\hline$\frac{\text { item_1 }_{5}^{-}}{}$ & 35.12 & 43.866 & .439 & .883 \\
\hline
\end{tabular}

Based on the results of validity test, it can be seen that all items of the instrument on teacher ability variables in identifying child development have $r$-count $0,870-0,883>$ from r-table 0,388 obtained from $\mathrm{N}=26$. If it is seen in the table above, then the result of r-count item no 1 to item no 15 can be seen that compared with $\mathrm{r}$-table, fifteen count is bigger than $\mathrm{r}$ table. Therefore, it can be concluded that the research instrument of the teacher's ability in identifying child development is valid, it means that the instrument used in this research can be used to measure teachers' ability.

THE RESULT OF INSTRUMENTS RELIABILITY Reliability Statistics

\begin{tabular}{rr}
\hline $\begin{array}{l}\text { Cronbach's } \\
\text { Alpha }\end{array}$ & \multicolumn{1}{c}{$\begin{array}{c}\text { N of } \\
\text { Items }\end{array}$} \\
\hline .885 & 15 \\
\hline
\end{tabular}


Moreover, based on the above table it can be seen that the value of alpha Cronbach on teacher ability variables is $0.885 \geq 0.60$. So it can be concluded that the instrument of research ability of teachers, especially pedagogic competence is considered reliable to be used as input on the process of analyzing data in testing the research hypothesis.

In the first stage, a pretest was applied once to the subject by distributing the questionnaires. This stage was done to measure a teacher's ability especially teacher pedagogic competence before using the screening assessment.

\section{STATISTICS OF \\ THE PRETEST OF \\ TEACHERS' ABILITY \\ STATISTICS}

\begin{tabular}{|c|r|}
\hline N $\quad$ Valid & 26 \\
Missing & 0 \\
Mean & 37.27 \\
Std. Error of Mean & 1.349 \\
Median & 37.50 \\
Std. Deviation & 6.879 \\
Variance & 47.325 \\
Range & 23 \\
Minimum & 25 \\
Maximum & 48 \\
Sum & 969 \\
\hline
\end{tabular}

Based on the table above, it can be seen that the descriptive analysis of pretest of teachers' ability related to the pedagogic competence which obtained from the average value of 37.27 with the highest value of the total number of 15 items is 48, the acquisition of the lowest is amount of 25 , and the acquisition of standard deviation is 6,879 .

\section{STATISTICS OF}

THE POSTTEST OF SCREENING

\begin{tabular}{|c|r|}
\hline \multicolumn{2}{|c|}{ ASSESSMENT } \\
\hline $\mathrm{N} \quad$ Valid & 26 \\
Missing & 0 \\
Mean & 55.38 \\
Std. Error of Mean & .222 \\
Median & 55.00 \\
Mode & 55 \\
Std. Deviation & 1.134 \\
Variance & 1.286 \\
Range & 5 \\
Minimum & 52 \\
Maximum & 57 \\
\hline
\end{tabular}

In addition, based on the table above, it can be seen that the posttest descriptive analysis of teacher ability related to pedagogic competence obtained the average value of 55.38 with the highest value of the total number of 15 items is 57 , the acquisition of the lowest number is 52 , and the acquisition of standard deviation is 1,134 .

Moreover, non-parametric statistics are used to test the hypothesis of the effect of screening the social-emotional development on teachers' ability in order to identify the development of playgroup children. The effect of using screening assessment on teachers' ability in identifying the development of playgroup children can be known by testing Wilcoxon.

THE TESTING RESULT OF WILCOXON PRETEST AND POSTTEST Ranks

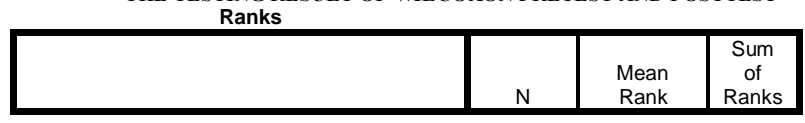

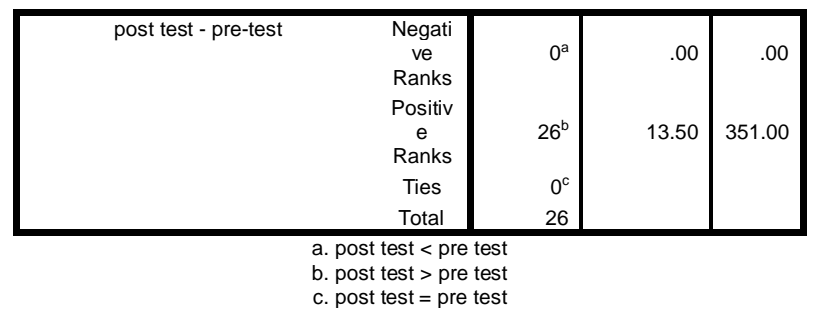

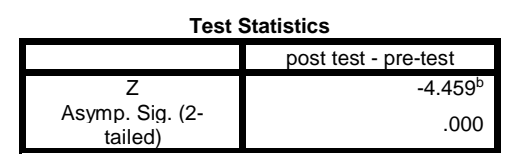

By looking at the table above, it is known that the value of Sig. (2-tailed) teachers' ability variables in identifying children development in the pretest and posttest have Sig. value. (2tailed) is 0.000 and below 0.05 , then $\mathrm{H} 0$ is rejected, therefore, it can be concluded that there are differences in the ability of teachers when pretest and posttest. This means that the use of screening assessment of social-emotional development affects the ability of teachers in identifying the development of playgroup children.

\section{CONCLUSION}

Using social-emotional development screening assessments influences the teachers' ability in identifying socio-emotional children's playgroup development in Sempu, Banyuwangi. It has been known from the difference of pretest and posttest result. The result of posttest average score of teacher ability is greater than the result of pretest average value before treatment is given. Judging from the average score, posttest result is greater than pretest that shows 55,38>37,27. These results indicate that this study proves the influence of the use of screening assessment of social-emotional development on teachers' ability in identifying the development of playgroup children. Wilcoxon test results note that the value of Sig. (2tailed) teacher's ability variables in identifying child development pretest and posttest have Sig value. (2-tailed) below 0.05 , it is 0.000 , then $\mathrm{H} 0$ is rejected and $\mathrm{H} 1$ is accepted so it can be concluded that there is the difference of teacher ability when pretest and posttest. This means that the use of screening assessment of social-emotional development affects the ability of teachers in identifying the development of playgroup children.

\section{REFERENCES}

[1] H. Indrijati, "Psikologi Perkembangan dan Pendidikan Anak Usia Dini.” Jakarta: Kencana Prenamedia Grup, 2016.

[2] G. S. Morrison, "Pendidikan anak usia dini saat ini." Yogyakarta: Pustaka Pelajar, 2016.

[3] J. W. Sentrock, "Perkembangan Anak Jilid 2," Jakarta: Erlangga, 2007.

[4] D. W. Johnson and R. T. Johnson, "Making cooperative learning work," Theory Pract., vol. 38, no. 2, pp. 67-73, 1999.

[5] T. Bergeson and M. A. Heuschel, "Characteristics of improved school districts: Themes from research," Retrieved March, vol. 7, p. 2012, 2004. 
[6] I. Yuwono, "IDENTIFIKASI DAN ASSEMEN ANAK BERKEBUTUHAN KHUSUS," Univ. Lambung Mangkurat.

[7] L. S. Sata, "Musings of a hyphenated American," Asian Am. Psychol. Perspect., pp. 150-156, 1973

[8] A. Nugraha and Y. Rachmawati, "Metode Pengembangan Sosial," 2014.

[9] H. Ö. DEMIRCAN and R. OLGAN, "Assessment in early childhood education: Commonly used curriculum models and Turkish curriculum," ons, 2011

[10] S. Arndt and M. Tesar, "Early childhood assessment in Aotearoa New Zealand: Critical perspectives and fresh openings," J. Pedagog., vol.
6, no. 2, pp. 71-86, 2015.

[11] S. A. Denham, H. H. Bassett, and K. Zinsser, "Early childhood teachers as socializers of young children's emotional competence," Early Child. Educ. J., vol. 40, no. 3, pp. 137-143, 2012.

[12] P. E. Latipun, "Malang.” UMM Press, 2002.

[13] M. Jannah, "Psikologi Eksperimen (Sebuah Pengantar." Surabaya: Unesa University Press, 2016.

[14] P. Sugiyono, “Dr. 2010," Metod. Penelit. Kuantitatif, Kualitatif, dan $R \& D$. Bandung CV Alf. 